\title{
METASTATIC MALIGNANT MELANOMA: CASE REPORT
}

\author{
Satish K. S. ${ }^{1}$, Sreedevi Chandrika M², Shwetha Gowda ${ }^{3}$
}

\section{HOW TO CITE THIS ARTICLE:}

Satish K. S, Sreedevi Chandrika M, Shwetha Gowda. "Metastatic Malignant Melanoma: Case Report". Journal of Evolution of Medical and Dental Sciences 2015; Vol. 4, Issue 50, June 22; Page: 8788-8791,

DOI: $10.14260 /$ jemds/2015/1274

ABSTRACT: A 32 years old man presented with well-defined lesion on the left sole 8 months back. Biopsy and FNAC from the lesion confirmed malignant melanoma left foot \& the patient was advised excision. After 4 months patient gave h/o swelling on the medial aspect of the thigh. The patient was diagnosed to have fulminant metastatic malignant melanoma of the left foot with metastasis to femoral lymph node. This case report re-emphasizes the importance of the combined approach to ascertain diagnose early.

KEYWORDS: Melanoma.

INTRODUCTION: REPORT: A 32 years old man presented with asymptomatic brownish black plaque on the sole of the left foot for 8 months (Figure A). H/o trauma 3 years back on the same site which was associated with mild pain, dull-aching in nature, aggravated on walking.He underwent electrocautery with subseqent recurrences. After a month, he noticed non-foul smelling seropurulent discharge from the same site. Patient was advised excision and the lesion was completely resolved (Figure B). It was followed 5 months later by an asymptomatic lump over the left groin that slowly increased in size (Figure G). No h/o fever, weight loss, anorexia or other systemic symptoms. His personal and family history were not contributary. Cutaneous examination revealed a brownish black plaque over the medial aspect of the left sole of the foot $4 \times 3 \mathrm{~cm}$ in size with irregular blurred margin.Left inguinal region showed asymptomatic swelling $3 \times 5 \mathrm{~cm}$ and enlarged lymph nodes that were multiple, matted, firm, mobile, non-tender. Right inguinal lymph nodes $\rightarrow$ normal. Rest of the mucocutaneous and systemic examination revealed no abnormality.

ROUTINE LAB INVESTIGATIONS: including haematological, biochemical, renal and liver function tests and radiological (X-ray foot, CT thorax, Usg abdomen) were within normal limits. Biopsy from the skin lesion showed features of malignant melanoma (Figure D, E, F), which was substantiated with the help of fontana masson and S-100 protein staining. FNAC from the left inguinal lymph nodes was consistent with metastatic melanoma.

HISTOPATHOLOGY: shows seen with a neoplasm composed of pleomorphic cells with vesicular cells and prominent nucleoli (Figure D, lower/ scanner). A diagnosis of disseminated malignant melanoma was established.The skin lesions were excised.Patient underwent left inguinal block dissection (Figure H ).

DISCUSSION: Cutaneous malignant melanoma is a tumour which arises from the melanocytic cells. ${ }^{1}$ It is an uncommon occurrence in the Asian population.The mortality is higher in the males, particularly in the young and the middle aged adults. ${ }^{2}$ Risk factors for the melanoma include-white race, familial history, Congenital mole, Immunosuppression, Genetic coding, Photosensitivity, Increased sun exposure, Increased number of nevocytic nevi. 


\begin{tabular}{|c|c|c|c|c|}
\hline $\begin{array}{c}\text { Type of } \\
\text { Melanoma }\end{array}$ & $\begin{array}{c}\text { Frequency } \\
\text { (\%) }\end{array}$ & Site & $\begin{array}{c}\text { Radial } \\
\text { Growth }\end{array}$ & $\begin{array}{c}\text { Special } \\
\text { Features }\end{array}$ \\
\hline $\begin{array}{c}\text { Superficial } \\
\text { spreading } \\
\text { melanoma }\end{array}$ & $60-70$ & $\begin{array}{c}\text { Any site, preference for } \\
\text { lower extremities } \\
\text { (women), trunk } \\
\text { (men and women) }\end{array}$ & Yes & $\begin{array}{c}\text { More pagetoid spread, } \\
\text { less solar elastosis }\end{array}$ \\
\hline $\begin{array}{c}\text { Nodular } \\
\text { melanoma }\end{array}$ & $15-30$ & $\begin{array}{c}\text { Any site, preference for } \\
\text { trunk, head, neck }\end{array}$ & No & $\begin{array}{c}\text { Nodule with more } \\
\text { rapid vertical growth }\end{array}$ \\
\hline $\begin{array}{c}\text { Lentigo } \\
\text { maligna } \\
\text { melanoma }\end{array}$ & $5-15$ & $\begin{array}{c}\text { Face, especially } \\
\text { nose and cheeks }\end{array}$ & $\begin{array}{c}\text { Slower growth over } \\
\text { years within sun- } \\
\text { damaged skin }\end{array}$ \\
\hline $\begin{array}{c}\text { Acral } \\
\text { lentiginous } \\
\text { melanoma }\end{array}$ & $5-10$ & $\begin{array}{c}\text { Palms, soles, } \\
\text { nail unit }\end{array}$ & Yes & $\begin{array}{c}\text { Most common } \\
\text { melanomatients with darker } \\
\text { pkin types }\end{array}$ \\
\hline \multicolumn{7}{|r|}{ Table 1: Types of primary cutaneous melanoma } \\
\hline
\end{tabular}

It has been proposed that melanomas progress through two phases-Radial (horizontal) growth phase (RGP). Vertical growth phase (VGP).

RGP: The melanoma cells remain confined to the epidermis, the dermo-epidermal junction and the papillary dermis. This is called melanoma-in-situ.

VGP: The melanoma cells invade the reticular dermis and ultimately the subcutis. This is represented as a nodule within the expanding lesion.The prognosis becomes less favourable In such cases. A preceding in-situ phase is seen in: Lentigo maligna, Superficial spreading melanoma, Acral lentiginous melanoma.The nodular melanoma arise de novo.Any patient having one cutaneous malignant melanoma has the risk of developing additional malignant melanomas.In our patient, the tumour probably originated at sole of the left foot and got metastasized to the left inguinal lymph nodes.

Figure A: Brownish black plaque on the sole of the left foot for 8 months.

Figure B: After excision.

Figure C: Pap stain showing pleomorphic cells, malignant nucleus with prominent nucleoli.

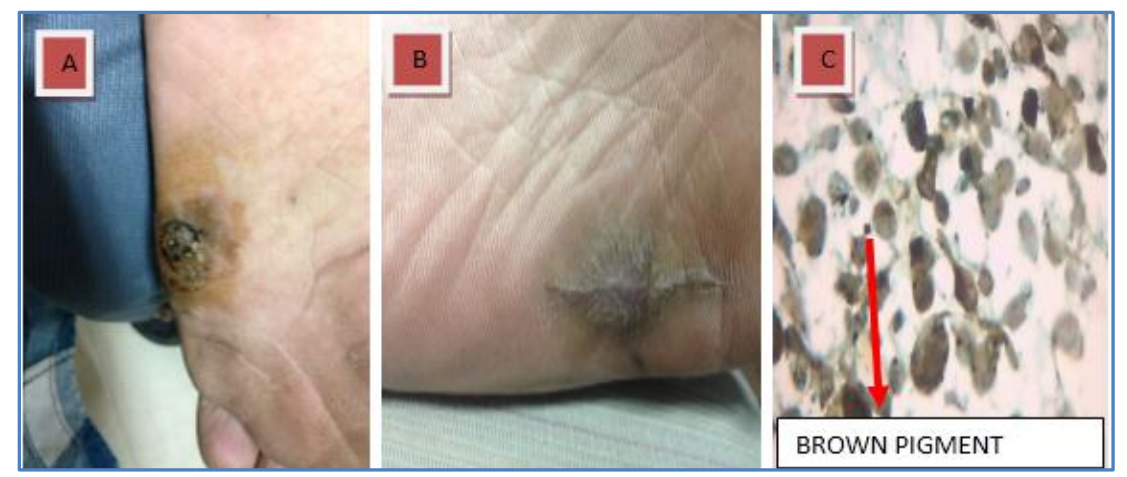

Fig. A, B \& C 


\section{CASE REPORT}

Figure D: HP-shows seen with a neoplasm composed of pleomorphic cells with vesicular cells and prominent nucleoli (Lower/ Scanner).

Figure E: HP-shows seen with a neoplasm composed of pleomorphic cells with vesicular cells and prominent nucleoli (High Power).

Figure F: Neoplastic cells show melanin pigment.

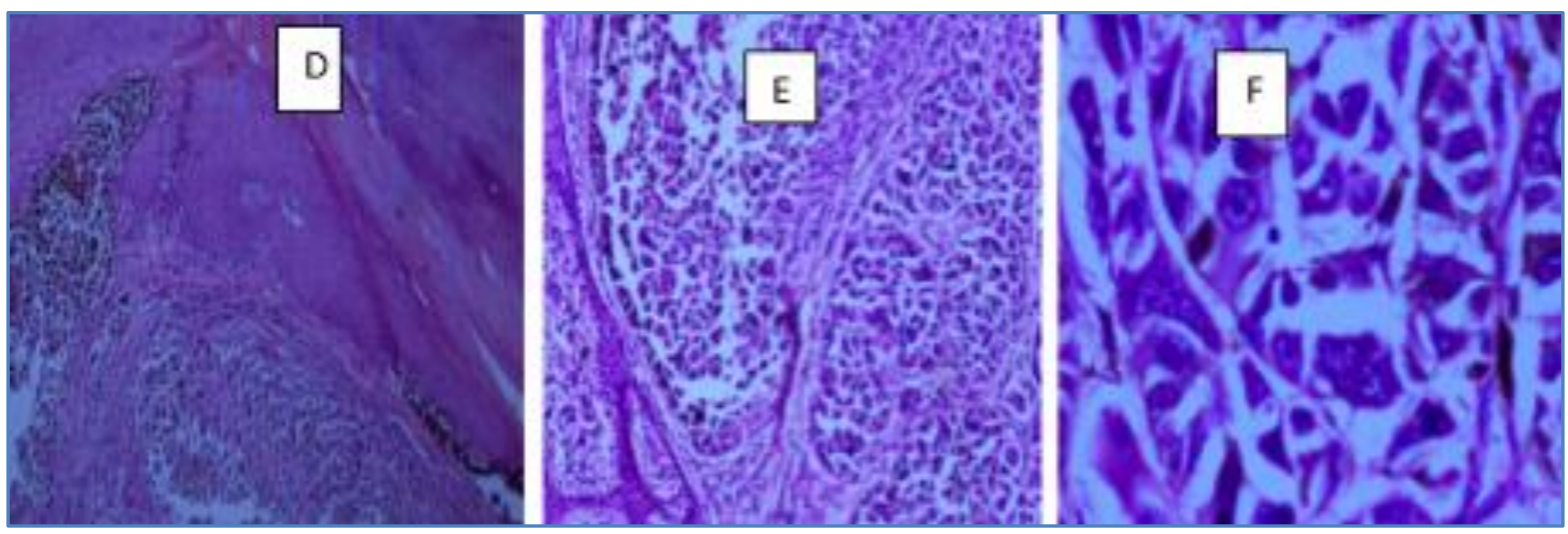

Fig. D, E \& F

Figure G: Metastatic lump over the left groin.

Figure H: Post left inguinal block dissection.

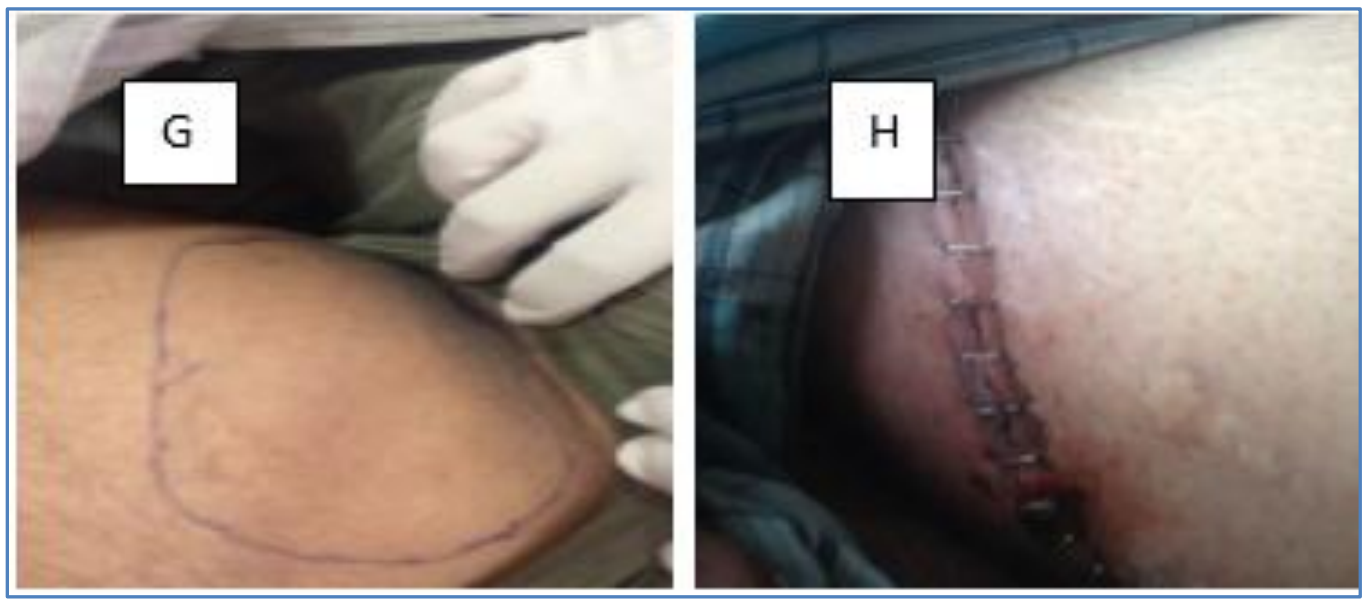

Fig. G \& H 


\section{CASE REPORT}

\section{REFERENCES:}

1. Black WC, Wiggins C.Melannoma among south western American Indians.Cancer 1985; 55: 2899-2902.

2. Kopf AW, kripkle ML, Stern RS.Sun and malignant melanoma 1984; 11: 674-684.

\section{AUTHORS:}

1. Satish K. S.

2. Sreedevi Chandrika M.

3. Shwetha Gowda

\section{PARTICULARS OF CONTRIBUTORS:}

1. Associate Professor, Department of Dermatology, KIMS, Bangalore.

2. Junior Resident, Department of Dermatology, KIMS, Bangalore.

FINANCIAL OR OTHER COMPETING INTERESTS: None
3. Senior Resident, Department of Dermatology, KIMS, Bangalore.

\section{NAME ADDRESS EMAIL ID OF THE} CORRESPONDING AUTHOR:

Dr. Satish K. S,

Associate Professor,

Department of Dermatology, KIMS, Bangalore.

E-mail: sksgowda4@gmail.com

Date of Submission: 09/01/2015.

Date of Peer Review: 10/01/2015.

Date of Acceptance: 30/05/2015.

Date of Publishing: 22/06/2015. 